\title{
The Democratic Case for a Basic Income ${ }^{1}$
}

\author{
LETICIA MORALES \\ Universidad Austral de Chile
}

\begin{abstract}
While most of its advocates justify the right to a basic income because it promotes individual freedom, autonomy and human development, an alternative line of argumentation insists that a universal basic income is a core component of a well-functioning democratic society. In this article I examine the democratic case for a basic income by engaging with the work of Carole Pateman and Michael Goodhart. More concretely, I argue that although their proposals offer interesting insights, they ultimately fail to properly justify the importance of a basic income on democratic grounds. I develop an alternative argument based on the right to political participation and explain why a universal basic income scheme may promote such right.
\end{abstract}

Keywords: democracy, political participation, material preconditions, social rights, income security, basic income.

\section{INTRODUCTION}

The right to income security poses something of a conundrum. While it is universally accepted that income is very important for the lives of human beings, the main international human rights treaties do not explicitly recognize a right to income security. Neither the Universal Declaration of Human Rights nor the International Covenant on Economic, Social and Cultural Rights directly proclaim a right to income security. However, they appear to do so indirectly through the right to social security, the right to

1 Previous versions of the paper were presented at the 8th Summer-School in Political Philosophy \& Public Policy (University of Minho), the 17th BIEN Congress in Lisbon, the Seminario Austral de la Universidad Austral de Chile, and the 2nd International Conference of the UK-Latin America Network for Political Philosophy (UKLAPPN) in Mexico City. I am grateful to the audiences at these events and to Jurgen De Wispelaere, Felicitas Holzer, Julio Montero and two anonymous referees for this journal for helpful comments and suggestions. 
an adequate standard of living and the right to work. ${ }^{2}$

Income security can be established in various ways (De Wispelaere and Morales 2016). The most common view links income to a wage obtained from work, social security payments or other state benefits, often subject to certain eligibility criteria and past contribution. In recent years, however, the proposal to grant each individual citizen a regular cash payment, without insisting on a means test or work requirements, has become popular in both academic and public policy debates (Van Parijs and Vanderborght 2017). The advocates of "basic income" - as the proposal is most commonly known - argue that granting each citizen or long-term resident an unconditional cash payment is the most effective way to ensure income security for all.

Unsurprisingly, this proposal is regarded as deeply controversial and there intense debate about its normative justification is ongoing. The most influential view tries to ground the right to basic income on the ideal of individual freedom. In this vein, Philippe Van Parijs - one of the pioneers in the basic income debate - famously sustained that basic income is a condition for securing real freedom, understood as the freedom to do whatever one might want to do (Van Parijs 1995; also Van Parijs and Vanderborght 2017). While freedom-based justifications have dominated the debate for years, some authors have emphasized the limitations of this approach. Such dissenters do not necessarily object to basic income as such; they merely reject the freedom-based justification because they think it fails to take into account some key structural features of contemporary societies. ${ }^{3}$ One such view proposes that, instead of freedom, we focus on democracy as the political value that could justify an unconditional basic income (Pateman 2002, 2003, 2004; Goodhart 2007, 2008; Van Damme, 2017).

In this article I explore the relationship between basic income and democracy. I start my analysis by focusing on the critique of Carole Pateman and Michael Goodhart against freedom-based justifications and

2 The Universal Declaration of Human Rights (UDHR) recognizes the right to social security (art. 22), the right to work (art. 23), and the right to a standard of living (art. 25). The International Covenant on Economic, Social and Cultural Rights (ICESCR) establishes the right to work (art. 7), the right to social security (art. 9), and the right to a minimum standard of living (art. 11).

3 Although some have argued against basic income on precisely such grounds. See, for instance, Gourevitch (2016). 
their attempt at grounding a democratic case for basic income. ${ }^{4}$ The writings of Pateman and Goodhart offer many interesting insights but in my view end up conflating a number of different democratic arguments. A first task of this article is to disentangle the strands of their argumentative web and separate out what I believe are importantly different mechanisms through which basic income could have a democratic impact. Upon reflection, it turns out not all of these different pathways to a democratic justification of basic income are convincing. I offer a two-fold critique of Pateman and Goodhart by first suggesting that both authors are unnecessarily wedded to an over-expansive ideal of democracy and, secondly, arguing that a basic income in many cases would fail to deliver on the democratic outcome they anticipate. The final section of this article constructs what I believe to be a more plausible democratic case for an unconditional basic income. Adapting a line of argument already found in Pateman and building on my earlier work on the democratic justification for social rights (Morales 2016), I examine the extent to which basic income constitutes a material precondition for the effective political participation of all citizens.

\section{BASIC INCOME: FROM INDIVIDUAL FREEDOM TO DEMOCRACY?}

A basic income is usually defined as an individual entitlement to receive a regular payment, independent of other sources of income, employment or willingness to work, or living situation (see Van Parijs and Vanderborght 2017: 5). It is very tempting to articulate the main value of such a basic income in terms of expanding a person's individual freedom as advocated most forcefully by Philippe Van Parijs (Van Parijs 1995). Of course, some authors reject Van Parijs' particular conception of freedom; instead, they value basic income because it promotes Republican freedom (Pettit 2012b; Taylor 2017), Rawlsian political liberalism (Birnbaum 2012), or "Independentarian" status freedom (Widerquist 2013). However, all these views share a crucial feature: they ground basic income on a certain account of individual freedom.

Carole Pateman - a leading democratic theorist - embraces the idea of an unconditional basic income, but firmly objects to the dominant

4 One restriction of this article is that I deliberately focus on the democratic case for basic income within a single state. In contrast to Goodhart (2007) I remain agnostic on the need to establish a global basic income or the role of basic income within single polities as a mechanism to further global democracy. The reason for this restricted focus is my emphasis on the role of democratic participation in the political system as typically represented in electoral democracies. 
freedom-based justification (Pateman 2003; 2004). ${ }^{5}$ Her main concern is that because this justification is entirely focused on social justice, liberal autonomy and individual freedom, it overlooks the impact a basic income may have on fundamental democratic values:

"Little attention has been paid in recent academic debates to the democratic significance of [...] a basic income. Participants have tended to focus on such questions as social justice, relief of poverty, equality of opportunity, or promotion of flexible labor markets, rather than democracy" (Pateman 2004: 91).

At the core of a democratic society, Pateman holds, lies the idea that "all citizens, women and men alike, have full standing and enjoy democratic rights and individual freedom" (Pateman 2003: 130). However, the reference to individual freedom should not be misinterpreted; it refers to self-government or autonomy and explicitly denotes "a political form of freedom in contrast to an economic form of freedom as individual opportunity" (Pateman 2003: 132). Pateman insists that political freedom must be prioritized: while individual opportunity has an important place within a democratic society, it is nevertheless "insufficient for democratization, the political process through which all citizens obtain full standing, and become first-class democratic citizens" (Pateman 2003: 132, added emphasis). By focusing on self-government and political freedom and its capacity to bring about the "necessary social and political change to create a robust democracy for all citizens" (Pateman 2003: 136), Pateman moves the justificatory goal posts away from excessively individualist approaches and towards a more structural perspective. In fact, her decisive objection against freedom-based justifications insists that "individual self-government depends not only on the opportunities available but also on the form of authority structure within which individuals interact with one another in their daily lives" (Pateman 2004: 91).

How does basic income feature within this democratic theory? I believe Pateman provides a patchwork of distinct arguments to answer this question. In the remainder of this section I briefly distinguish four of them.

First, Pateman highlights the democratic significance of a universal basic income by analogy to the historical and institutional role played by universal suffrage. Suggesting that basic income and the right to vote are comparable, she writes "a basic income should be seen as a fundamental

5 At the time, Pateman's focus was primarily on Van Parijs (1995) and the debate his work inspired in political philosophy. Pateman's critique thus predates the "new wave" of freedom-based justifications of basic income, such as Pettit (2012b) or Widerquist (2013). 
or democratic right, like universal suffrage" (Pateman 2003: 131). Universal suffrage means that every member of a polity is entitled to participate in the electoral process, perhaps subject to certain minimal qualifications, such as age or residence. The key aspect here is that any barriers that make it harder for citizens to demonstrate their qualification to vote - e.g., cumbersome voting registration laws - are deemed undemocratic. Similarly, Pateman sustains that all citizens must be entitled to a basic income because they are adult members of the polity (Pateman 2003: 146). ${ }^{6}$ The right to basic income and the right to vote are analogous in the sense that both are entitlements that every citizen must enjoy as such. When their enjoyment is subject to further conditions they turn into a privilege rather than a right (Pateman 2003: 146; 2004: 102). In Pateman's view, just like adding strict voting registration requirements frustrates access to voting, adding work requirements or means testing hampers access to the basic income citizens are entitled to.

Second, Pateman suggests that a basic income is necessary because it "provides the lifelong security that helps safeguard other rights" (Pateman 2004: 94). Michael Goodhart has defended this view in more detail. His starting point is a justification of social and economic rights - including a right to guaranteed subsistence - as essential to secure emancipation and the enjoyment of other basic rights (Goodhart 2007:94, 2008). He maintains that the fundamental right to guaranteed subsistence requires the social provision of a basic income (Goodhart 2007: 106) and insists that such income is an integral part of a democratic perspective because "its primary justification is its role in achieving and securing emancipation for all members of society" (Goodhart 2007: 107). In Goodhart's view, basic income therefore is a desirable scheme because it "satisfies the fundamental economic right to a guaranteed subsistence that democracy demands" (Goodhart 2007: 109).

Third, Pateman insists that democratic citizenship requires equal social standing, understood as a relational notion that captures "the form of authority structure within which individuals interact with one another in their daily lives" (Pateman 2004: 91). Democratic standing informs both how individuals perceive themselves in relation to others and how they perceive others. In this respect, Pateman (2004: 94) finds inspiration in the writings of sociologist T.H. Marshall (1950), who divides citizenship into three different components - civil rights, political rights and social rights - and maintains that social citizenship involves an equality of status which requires "a direct sense of community membership based on loyalty to a

6 In many proposals children and adults are covered by slightly different schemes (Van Parijs and Vanderborght 2017). 
civilization which is a common possession" (Marshall 1950: 40-41). Basic income presents an appealing way to guarantee equally social standing: unconditionally securing a basic income to everyone avoids a person who would otherwise be subject to a controlling sanctioning welfare regime to be treated as "second-class citizens".

In a similar vein, Pateman argues that a universal basic income is valuable because it helps "to remove the temptation for some citizens to see others as less worthy of respect, and so as lesser citizens, because of their lack of economic resources" (Pateman 2003: 146). Pateman famously extends this idea of democratic citizenship to emphasize its potential in advancing the freedom and full social standing of women (Pateman 2004: 90). This implies revisiting the social institutions of family, marriage and employment, and the extent to which these traditionally frustrated "the standing of wives as citizens" (Pateman 2004: 98). Critically, a basic income "is a crucial part of any strategy for democratic social change" by virtue of its capacity to "break the long-standing link between income and employment and end the mutual reinforcement of the institutions of marriage, employment, and citizenship" (Pateman 2004: 90). In other words, for Pateman, basic income plays an important democratic role by promoting full social standing of citizens in general, and women in particular, in the different spheres of life.

Fourth, Pateman argues for the democratic potential of a universal basic income by reference to an important opportunity it creates, namely the freedom not to be employed (Pateman 2004: 92). The reason why basic income has a significant democratic potential is that it improves the capacity of individuals "to refuse to enter or to leave relationships that violate individual self-government or that involve unsafe, unhealthy, or demeaning conditions" (Pateman 2004: 96). Furthermore, basic income also promotes citizens' participation in collective self-government by opening up "opportunities for citizens to develop their political capacities and skills" and ensuring "that participation in social and political life would not require heroic efforts on the part of any citizens" (Pateman 2004: 96). ${ }^{7}$ The focus on increased opportunities allows Pateman to explicitly link basic income with the ideal of democratization:

"by opening up this range of opportunities and uncoupling income and standard of life from employment, a basic income has the potential both to encourage critical reassessment of the mutually reinforcing structures of marriage, employment, and citizenship and to open the

$7 \quad$ Pateman (2004: 97) writes: "a basic income would allow individuals at any time to do voluntary or political work, for example, to learn to surf, to write or paint, to devote themselves to family life, or to have a quiet period of self-reassessment or contemplation." 
possibility that these institutions could be remade in a new, more democratic form" (Pateman 2004: 97).

In sum, the democratic case for basic income, as outlined in the writings of Carole Pateman $(2003,2004)$ and Michael Goodhart $(2007,2008)$ can be understood as the mutually reinforcing combination of four distinct arguments. Together these paint a picture by which an unconditional basic income represents the economic analogy of universal suffrage which, by securing the equal enjoyment of fundamental human rights, promotes the full social standing and equal range of political and social opportunities for all citizens.

\section{DEMOCRACY AND BASIC INCOME: A CRITICAL ASSESSMENT}

Pateman and Goodhart justify basic income from a democratic perspective by assuming a substantive conception of democracy. However, substantive conceptions of democracy often fail to appreciate "value pluralism by neglecting the constitutive role of democratic decision-making processes for groups of individual agents who try to determine how they should act together" (Peter 2009:2-3). A set of valuable outcomes is posited in advance and constrains the decision-making process (e.g., Goodhart 2008: 150), neglecting other alternative goals that citizens may reasonably want to advance. As Waldron (1999) has forcefully pointed out, this view fails to take deep political and moral disagreement seriously. Furthermore, substantive conceptions of democracy also blur the lines between democracy and social justice, failing to give proper due to democratic legitimacy as a distinct political value (Pettit 2012a: 59; Morales 2015).

Michael Goodhart insists that because substantive conceptions of democracy highlight the democratic importance of human rights, they contribute to the revival of "democracy itself, which in its atrophied electoral and procedural forms can seem like a fairly moribund and uninspiring ideal" (Goodhart 2007: 98). But in order to avoid the kind of "atrophied" democracy represented by procedural models of aggregative democracy that give primacy to the formal right to vote and Schumpeterian elite competition, it is not necessary to turn democracy into a substantive conception of social justice with predetermined social outcomes. As Phillip Pettit explains:

"Normative thinking about legal, political, and social institutions has been dominated over the past quarter century or more by the ideal of justice, in particular social or distributive justice. This focus on justice 
is unfortunate, because it has suggested that there is only one basic ideal that we need to think about in our normative projects. It is unfortunate, in particular, because it puts out of the picture the very different sort of ideal to which I give the name of legitimacy specifically, political legitimacy" (Pettit 2012a: 59).

Michael Goodhart, for instance, clearly adopts such an unfortunate position when he suggests that democracy is only instrumentally justified as a means to achieving emancipation through the enjoyment of fundamental rights (Goodhart 2007: 103; 2008: 150). In the next section I propose an alternative democratic model centered on political participation that avoids atrophied proceduralism without collapsing political legitimacy into social justice.

The Pateman-Goodhart approach to democratization is also problematic because they explicitly extend democracy to the family, the workplace and the economy (Pateman 2003, 2004). Goodhart holds that "certain institutions are more democratic than others, precisely because they are instrumental in securing fundamental human rights"; yet this also implies that "many rights can be secured differently in different contexts" (Goodhart 2008: 150). Unfortunately, this view overlooks that democracy is mainly a framework for collective decision making within a political system: its fundamental aim is to ensure that collective decisions are legitimate (Peter 2009).

These theoretical difficulties pose a practical and strategic problem: the sort of basic income scheme required to satisfy the goals that Pateman and Goodhart have in mind may be too radical or too demanding under present-day socio-economic conditions. The more moderate basic income schemes currently under consideration around the world are not likely to have the democratic impact Pateman and Goodhart are hoping for. To illustrate this problem, I re-examine the four arguments outlined in the previous section.

To begin with, the analogy between a universal right to vote and a universal right to basic income has some initial plausibility. ${ }^{8}$ However, these rights differ in important aspects. The right to vote is often explained through the egalitarian formula "one person, one vote". Similarly, basic income may also be articulated through the formula "one person, one basic income". But is there any deeper reason to accept the analogy between both rights? Pateman observes that "universal suffrage is the

8 Pateman, along with many others, views basic income as a right but see the discussion of why conceiving basic income as a right is problematic in De Wispelaere and Morales (2016). 
emblem of equal citizenship", which is further explained by reference to "an orderly change of government through free and fair elections" (Pateman 2004: 94). It is generally accepted that a person cannot be a citizen without the right to vote (King and Waldron 1988). Along similar lines, Pateman tries to argue that "a basic income is the emblem of full citizenship", because "basic income as a democratic right is necessary for individual freedom as self-government" (Pateman 2004: 94-95). However, it is dubious that granting people a modest basic income will suffice to ensure the kind of equal citizenship Pateman proposes. Even though basic income offers a floor (Van Parijs and Vanderborght 2017), it may fail to block the vast differentials in income and wealth - and, therefore, of power - that characterize contemporary societies (Casassas and De Wispelaere 2016).

Second, Pateman and especially Goodhart maintain that basic income is meant to help to secure the equal enjoyment of universal human rights across different social spheres, including the family, employment and citizenship. Through the secure enjoyment of human rights, basic income helps to change the structure of oppressive institutions. Yet the kind of basic income that could secure the enjoyment of fundamental rights - "the minimum necessary to secure rights and emancipation" (Goodhart 2007: 105) - would most likely be unfeasible under current conditions. ${ }^{9}$ However, the tenet that a basic income may promote the emancipation of women within the family is subject to considerable debate (e.g., Robeyns 2001; Zelleke 2011). Some Feminist authors argue that a basic income may end up reinforcing traditional gender roles as it may cause women to disproportionately exit the labor market (Robeyns 2001: 100-102). ${ }^{10}$ Similarly, the view that basic income will emancipate workers has also been challenged (Gourevitch 2016; Birnbaum and De Wispelaere 2016). The argument advanced by Pateman and Goodhart relies on basic income improving the bargaining position of workers vis-a-vis employers by granting workers an exit option. But on realistic assumptions of how

9 Additionally, Goodhart's democratic argument appears to be circular. If all fundamental basic rights must be achieved in order to obtain emancipation, and if basic income's failure to protect one right means no single right is protected (because of their interdependence), then the securement of other fundamental rights never could be justified if not by a democratic decision-making process where the fundamental basic right to participation is secured. But for Goodhart the right to participation can be left aside if there is another political organization that can guarantee other rights, such as an absolutist government, destroying the very notion of interdependent fundamental rights.

10 Robeyns concludes that basic income does not reduce gender injustice, and it is necessary for it to be "supplemented with other social policy measures that liberate women", including "the transformation of certain cultural and social patterns, like gender roles and gender hierarchies, which are now constraining individuals in their freedom" (Robeyns 2001: 103). 
contemporary labor markets work, "an exit strategy might end up worsening rather than strengthening the opportunity set and bargaining position of the most vulnerable workers" (Birnbaum and De Wispelaere 2016: 61).

A democratic case for basic income that relies on basic income being able to substantially secure a set of fundamental rights in order to promote genuine emancipation and democratization appears too tall an order for a realistic basic income scheme to satisfy. This puts Pateman and Goodhart at risk of being caught between the rock of downgrading the fulfillment of fundamental rights and the hard place of insisting on an utterly impractical basic income ideal. ${ }^{11}$

Third, as I have already mentioned, Pateman views democratic citizenship as a form of social standing. Building on the work of T.H. Marshall allows her to extend citizenship into the economic sphere by arguing that social and economic rights play a constitutive role in the equal standing of citizens. Being denied this equal standing amounts to a person being relegated to second-class citizenship or even denizenship (Standing 2012). Importantly, equal social standing requires independence and freedom from oppression and domination within the prevailing institutions of marriage, family, and employment. Once more, this idea is problematic because the sort of basic income policy that would promote such genuine independence would be unfeasible under current conditions. Without a clear sense of what level of basic income would be deemed sufficient to ensure the required independence it is difficult to assess whether a feasible basic income scheme contributes to democratization in the desired manner.

Finally, Pateman insists that basic income promotes a bundle of social and political opportunities, including those that follow from the freedom not to be employed. This includes opportunities to support individuals' political participation in the decision making-process, opportunities for citizens to develop their political capacities and skills, and opportunities to do political work. These are all very relevant and important opportunities that directly connect basic income with democracy. However, two problems remain. On the one hand, Pateman offers no clear account of how precisely a basic income would improve political participation or democratic skills. What social or institutional levers does basic income

11 Goodhart appears to bite the bullet when proposing basic income not as a welfare or poverty reduction program, but rather as a democratic entitlement that "costs more and delivers more; the value of what it delivers is ultimately a measure of our political commitments" (Goodhart 2008: 155). Of course this does not make basic income politically feasible. 
pull and how does this impact on democratic opportunities? On the other hand, for Pateman basic income appears to impact primarily by granting workers the opportunity to refuse employment. As mentioned before, recent research casts doubt on whether basic income is able to achieve such a robust "right to exit" or even have any meaningful impact on the democratic nature of employment relations (Birnbaum and De Wispelaere 2016). But even if that were the case, there is something fundamentally flawed about a view that depends on freedom from employment as a mediating mechanism to make a democratic argument stick. What about the democratic impact of basic income on workers' political opportunities? If indeed freedom from work was the main pathway through which basic income secures democratic values and objectives, this would surely reduce its scope and democratic impact.

When considered together, these objections suggest that in spite of its initial plausibility, the freedom to exit the labor market may make no real contribution to individual self-government. What we need is an argument that explains why a basic income may improve individuals' opportunities to participate in the political process that does not exclusively depend on the freedom to exit employment. I provide such argument in the next section.

\section{THE DEMOCRATIC ARGUMENT FOR BASIC INCOME REVISITED}

In this final section I offer a democratic argument for basic income that builds on the work of Pateman but avoids the pitfalls I have discussed previously. Collective decisions are considered legitimate if they result from a decision-making process that satisfies the necessary formal and material conditions that secure the participation of all citizens (Peter 2009: 4). On this view, political participation is the foundation of legitimate political authority because it respects the equal moral agency of each citizen. Political citizenship essentially refers to the right to political participation in the decision-making processes of the polity (Waldron 1999).

This right must be universally realized: no citizen should be excluded either on formal or material grounds (Morales 2015, 2017). Formal exclusion occurs when institutional rules prevent some citizens from exercising their right to political participation. Material exclusion takes place when citizens fail to participate because they lack certain material resources even if no formal rule prevents them from doing so. In liberal democratic theory, the right to political participation is typically interpreted in formal 
terms. However, the legal recognition of a formal right to political participation is insufficient to guarantee the effective political participation of all. This raises a fundamental question: why must a citizen accept the authority of a political decision when she is materially unable to exercise her formal right to participate? Why should citizens accept political authority in cases where they are formally included but practically excluded from participation in the decision-making process? Real life examples of such a disjunction between formal and material right to political participation are plentiful, especially regarding the right to vote. Some political systems impose burdensome requirements of voter registration, which effectively disenfranchise otherwise eligible voters. Other systems may facilitate registration but many voters are unable to reach the polling booth because of a lack of transport or inability to take time off work. A formal interpretation of the right to vote - understood as a subset of the broader right to political participation - appears too weak to establish the legitimacy of a political system.

The tenet that democratic decisions are legitimate because every citizen has an effective opportunity to participate in the decision making process does not imply that individuals must be treated equally in all domains of life - be it the family, the workplace, or the marketplace. Although all domains of life can be considered as political - as Feminists such as Pateman have rightly argued - there are relevant differences between the political domain and other social spheres. Several arguments may justify a more extensive or generous conception of equality in the social and economic realm; yet this is fully compatible with thinking that the political system is where legitimate processes of collective decision-making take place under conditions that must ensure the political participation of all citizens. Importantly, this view implies no commitment to the sort of atrophied electoral proceduralism that Pateman and Goodhart have criticized.

Legitimate political participation is not restricted to voting in a formal election, campaigning for a candidate, or having the opportunity to run for public office, as Schumpeterians maintain. The concept of political participation must be broadened to include a host of other political acts provided they are "structurally embedded in the political system" (Cicatiello, Ercolano and Gaeta 2015: 448-449). Thus, the actions of public interest groups, civil organizations or social movements aimed at lobbying political decision-makers are rightly regarded as instances of political participation. Even acts of civil disobedience and protest at the margins of the social order - such as boycotts or the occupation of public offices - can be considered forms of political participation, for they too are aimed at 
directly or indirectly influencing decision-makers. ${ }^{12}$ What unites this wide range of political activities is that they all contribute to the democratic process "by which citizens can communicate information about their interests, preferences and needs to the government" (Bovens and Wille 2010: 395). Adopting a broad view of political participation that includes both "conventional" and "unconventional" forms of political action (Cicatiello, Ercolano and Gaeta 2015) situates my account of political democracy between advocates of a Schumpeterian electoral democracy and the more expansive emancipatory democratic model advocated by Pateman and Goodhart.

The intermediate model I propose implies that a genuine democracy must ensure that citizens have access to the full range of political participation activities, not merely a right to vote or stand in an election. Contestatory measures such as access to courts to challenge legislation or to engage in social protest are equally important (Pettit 2012b). That said, since most citizens engage in unconventional participation when they feel excluded from conventional forms of participation - e.g., people protest when they feel they have no real voice in an election - we should focus on conventional political participation in the first instance. Securing access to unconventional political participation is a second-best solution to a political system that has failed to include all citizens in conventional politics. With these building blocks in place, let us now examine the role of an unconditional basic income.

The democratic case for basic income depends on establishing a firm link between basic income and its expected impact on political participation. The idea that citizens need a guaranteed income to effectively participate in the legitimate democratic process is hardly a novel thought:

"Almost all of the great theorists of citizenship [...] have believed that in order to be a citizen of a polis, in order to be able to participate fully in public life, one needed to be in a certain socio-economic position. [...] People, it was said, could not act as citizens at all, or could not be expected to act well in the political sphere and to make adequate decisions, unless some attention was paid to matters of their wealth, their well-being and their social and economic status" (King and Waldron 1988: 425-426).

Contemporary democratic societies do not restrict the formal political

12 Political participation at the margin of the social order may skirt what is deemed legal at any given time. The legality of protest and other unconventional political acts is a complicated matter. 
participation of poor or economically disadvantaged people any longer: political rights are accorded to all citizens equally and no one can be politically excluded on the basis of social and economic status. Nevertheless, lack of money or income inequality continue to affect political participation even today.

Should income be regarded as a material precondition for political participation? The role of money in politics is indisputable: "money is an important political resource for any group, but it takes special significance for people who live at or near poverty levels" (Verba, Schlozman, and Brady 1995: 288-303). A recent study confirms this view: "[t]he higher (lower) individual income is, the higher (lower) individual engagement in conventional and unconventional political activities is" (Cicatiello, Ercolano and Gaeta 2015: 451). In fact, "income may be considered the most important individual-level determinant of political participation; all political activities are costly because resources (time, money, skills) must be invested in order to carry them out" (Cicatiello, Ercolano and Gaeta 2015: 450). Of course, the relevance of money should not lead us to underestimate other important structural obstacles to political participation. ${ }^{13} \mathrm{~A}$ universal basic income may be unable to eradicate many structural barriers that continue to exist in contemporary societies including those related to religion, ethnicity, or gender. Basic income is only a partial solution to practical disenfranchisement in contemporary politics. Still, poverty and income inequality are also important structural obstacles that prevent those at the bottom of the income distribution from exercising their equal right to political participation. To the extent that poverty and income inequality undermine political participation, the democratic case for a basic income is a promising avenue to explore.

The main question is why money matters more for the political participation of those living at or near poverty, which presumably is where we would expect a basic income scheme to have its most pronounced effect? In other words, what is the mechanism that allows basic income to impact on a citizen's ability to participate in political life? First, we might expect basic income to have a direct effect on the sort of costly actions that active citizens must engage in. For instance, basic income may help people afford the costs of voting registration or transport to the polling booth. Likewise, it may help to finance political campaigns: Obama's presidential campaign was famously funded through numerous small donations from poor supporters. In spite of this, we might ask why a basic income is the best response to the reduced participation of the poor. Perhaps more targeted policies, such as subsidized registration or free public transport

13 I thank a referee for this journal for pressing me to clarify this point. 
during the election day, are better. Furthermore, when resources are scarce, using money to promote participation involves significant opportunity costs for the poor because such money could be invested in providing them secure access to nutritious food, housing or medical care. Finally, any moderate basic income scheme will most likely not suffice to support a number of important instances of political participation, thereby failing to fully satisfy the requirements of political inclusion. So it seems that when it comes to direct costs, more targeted solutions may perform better than a universal basic income.

The democratic value of a basic income is better appreciated when we consider the indirect effects that (the lack of) money has on political participation. For instance, a basic income may create incentives to participate through conventional channels because citizens will most probably want to defend a public policy that benefits them (Campbell 2003). In other words, a basic income might politicize citizens because it gives them a stake in society (Dowding, De Wispelaere and White 2003). Relatedly, those who cannot "live the lives of a civilized being according to the standards prevailing in the society risk marginalization and shame", which translates in political distrust and subsequently in reduced participation (Soss 2005: 306, citing Marshall 1964: 72). Unlike highly selective and conditional programs, a basic income would avoid negative experiences with case workers and other "representatives" of the state, therefore boosting political participation (Soss 2005; Bruch, Ferree and Soss 2010). ${ }^{14}$

In addition, "the daily struggle to make ends meet leaves individuals with little time or energy to follow the public debate, participate in political organizations, or hold elected representatives accountable" (Soss 2005: 306). Recent research has even suggested that poverty implies a genuine "scarcity mindset" with cognitive bandwidth restricted to survival activities (Mani et al. 2013). Finally, political decision-makers respond differently to distinct "target populations", such that "policies for disadvantaged groups will isolate or stigmatize their targets, setting them apart from the majority as an object of pity or scorn" (Soss 2005: 294). One expected effect of the universalism of a basic income policy is that it might escape such easy targeting by decision-makers.

In sum, through a variety of pathways basic income could have indirect positive effects on poor citizens' political participation by freeing up time, energy and "cognitive bandwidth", and by positively affecting their status

14 However, a recent study of the Bolsa Familia program in Brazil suggests much also depends on how selective programs themselves are framed (Hunter and Borges Sugiyama 2014). 
and beliefs about themselves and others. The democratic hope is that basic income can generate a virtuous circle, through which an increased participation of the poor will bring about more responsiveness to their plights; and this will in turn reinforce participation.

\section{CONCLUSION}

In this article I have examined the democratic case for basic income. The idea that basic income should be justified not by reference to individual freedom but because of its impact on democratic citizenship was pioneered by Carole Pateman and developed by Michael Goodhart. However, I find that their approach fails to establish a robust case for basic income on democratic grounds. One major issue is that neither Pateman nor Goodhart offer a clear account of the pathways by which a basic income produces democratic value. Another major obstacle is that the kind of basic income their expansive model of democracy calls for is unfeasible under present conditions. I sustain that a more modest model of democracy that prioritizes broad and effective political participation in decision-making processes, offers a more plausible democratic case for a universal basic income. Recent research by political scientists has established a number of mechanisms through which low income and poverty negatively impacts on political participation. Granting each citizen an unconditional and secure basic income is a promising remedy to rectify this problem.

\section{BIBLIOGRAPHY}

Birnbaum, S., 2012: Basic Income Reconsidered: Social Justice, Liberalism and the Demands of Equality, New York, Palgrave Macmillan.

Birnbaum, S. and De Wispelaere, J. 2016: "Basic Income in the Capitalist Economy: The Mirage of 'Exit' From Employment”, Basic Income Studies 11(1): 61-74.

Bovens, M. and A. Wille, 2010:”The Education Gap in Participation and Its Political Consequences", Acta Politica 45: 393-422.

Bruch S., Ferree, M. and Soss, J., 2010: "From Policy to Polity: Democracy, Paternalism, and the Incorporation of Disadvantaged Citizens", American Sociological Review 75(2): 205-226.

Casassas, D. and De Wispelaere, J., 2016: "Republicanism and the political economy of democracy”, European Journal of Social Theory 19 (2): 283-300.

Cicatiello, L., Ercolano, S. and Gaeta, G., 2015: "Income distribution and political participation: a multilevel analysis", Empirica 42: 447-479.

De Wispelaere, J. and Morales, L., 2016: "Is there (or should there be) a right to basic income?", Philosophy and Social Criticism 42(9): 920-936.

Dowding, K., De Wispelaere, J. and White, S. (eds.), 2003: The Ethics of Stakeholding, Basingstoke, Palgrave MacMillan. 
Goodhart, M., 2007: “None So Poor that He is Compelled to Sell Himself'; Democracy, Subsistence, and Basic Income”, in L. Minkler and S. Hertel (eds.), Economic Rights, Cambridge, Cambridge University Press.

- 2008: “A Democratic Defense of Universal Basic Income”, in I. M. Young, M. L. Shanley, and D. I. O'Neill (eds.), Illusion of Consent: Essays after Carole Pateman, State College, PA, Pennsylvania State University Press.

Gourevitch, A., 2016: “The Limits of a Basic Income: Means and Ends of Workplace Democracy”, Basic Income Studies 11(1): 17-28.

Hunter, W. and Borges Sugiyama, N., 2014: “Transforming Subjects Into Citizens: Insights From Brazil's Bolsa Familia”, Perspectives on Politics 12(4): 829-45.

King, D. and Waldron, J., 1988: "Citizenship, Social Citizenship and the Defense of Welfare Provision”, British Journal of Political Science 18(4): 415-443.

Mani, A, Mullainathan, S., Shafir, E., and Zhao, J., 2013: "Poverty Impedes Cognitive Function", Science 341(6149): 976-980.

Marshall, T.H., 1950: Citizenship and Social Class, Cambridge, Cambridge University Press.

Morales, L., 2015: Derechos sociales constitucionales y democracia, BarcelonaMadrid, Marcial Pons.

- 2017: "The Discontent of Social and Economic Rights", Res Publica 24(2): 257272.

Pateman, C., 2002: "Self-Ownership and Property in the Person: Democratization and a Tale of Two Concepts", Journal of Political Philosophy 10(1): 20-53.

- 2003: "Freedom and Democratization: Why Basic Income is to be preferred to Basic Capital", in K. Dowding et al. (eds.), The Ethics of Stakeholding, Palgrave Macmillan, London.

- 2004: "Democratizing Citizenship: Some Advantages of a Basic Income", Politics and Society 32(1): 89-105.

Peter, F., 2009: Democratic Legitimacy, New York, Rutledge Studies in Social and Political Thought.

Pettit, P., 2012a: "Legitimacy and Justice in Republican Perspective", Current Legal Problems 65: 59-82.

- 2012a: On People Terms. A Republican Theory and Model of Democracy, Cambridge, Cambridge University Press.

Robeyns, I., 2001: “Will a Basic Income Do Justice to Women?", Analyse und Kritik 23(1): 88-105.

Soss, J., 2005: "Making Clients and Citizens: Welfare Policy as a Source of Status, Belief, and Action”, in Anne L. Schneider and Helen M. Ingram (eds.), Deserving and Entitled. Social Constructions and Public Policy, New York, State University of New York Press.

Standing, G., 2012: “The Precariat: From Denizens to Citizens?”, Polity 44(4): 588608.

Taylor, R.S., 2017: Exit Left: Markets and Mobility in Republican Thought, Oxford, Oxford University Press.

Van Parijs, P., 1995: Real Freedom for All: What (if anything) can justify capitalism, Oxford, Oxford Political Theory.

Van Parijs, P. and Vanderborght, Y. 2017: Basic Income. A Radical Proposal for a Free Society and a Sane Economy, Cambridge, Harvard University Press. 
Verba, S., Schlozman, K., and Brady, H.E., 1995: Voice and Equality: Civic Voluntarism in American Politics, Cambridge, Harvard University Press.

Waldron, J., 1999: Law and Disagreement, Oxford, Oxford University Press.

Widerquist, K., 2013: Independence, Propertylessness and Basic Income, Basingstoke, Palgrave Macmillan.

Zelleke, A. 2011: "Feminist Political Theory and the Argument for an Unconditional Basic Income”, Policy and Politics 39(1): 27-42. 